\title{
Evaluation of skin absorption of drugs from topical and transdermal formulations
}

\author{
André Luís Morais Ruela ${ }^{1}$, Aline Gravinez Perissinato², Mônica Esselin de Sousa Lino ${ }^{3}$, \\ Paula Silva Mudrik³, Gislaine Ribeiro Pereira ${ }^{3 *}$
}

\begin{abstract}
${ }^{1}$ Multidisciplinary Health Institute, Federal University of Bahia, Vitória da Conquista, BA, Brazil, ${ }^{2}$ School of Pharmaceutical Sciences Universidade Estadual Paulista, Araraquara, SP, Brazil, ${ }^{3}$ Departament of Pharmacy, Faculty of Pharmaceutical Sciences, Federal University of Alfenas, Alfenas, MG, Brazil
\end{abstract}

\begin{abstract}
The skin barrier function has been attributed to the stratum corneum and represents a major challenge in clinical practice pertaining to cutaneous administration of drugs. Despite this, a large number of bioactive compounds have been successfully administered via cutaneous administration because of advances in the design of topical and transdermal formulations. In vitro and in vivo evaluations of these novel drug delivery systems are necessary to characterize their quality and efficacy. This review covers the most well-known methods for assessing the cutaneous absorption of drugs as an auxiliary tool for pharmaceutical formulation scientists in the design of drug delivery systems. In vitro methods as skin permeation assays using Franz-type diffusion cells, cutaneous retention and tape-stripping methods to study the cutaneous penetration of drugs, and in vivo evaluations as pre-clinical pharmacokinetic studies in animal models are discussed. Alternative approaches to cutaneous microdialysis are also covered. Recent advances in research on skin absorption of drugs and the effect of skin absorption enhancers, as investigated using confocal laser scanning microscopy, Raman confocal microscopy, and attenuated total reflectance Fourier-transform infrared spectroscopy, are reviewed.
\end{abstract}

Uniterms: Skin absorption/effects/study. Skin absorption/topical formulations. Skin absorption/ transdermal formulations. Skin absorptions/enhancers.

\section{INTRODUCTION}

Topical and transdermal drug delivery systems have shown significant advantages in clinical practice for drug targeting to the action site in the body; this has reduced the systemic side effects. The administration of drugs by through the skin is also performed to achieve controlled or prolonged drug delivery, and this route can be explored as an alternative to the oral route. The oral route shows some limitations for drugs with irregular absorption in the gastrointestinal tract and low bioavailability and for drugs with increased first pass metabolism and short plasma halflife times (Barry, 2001; Wokovich et al., 2006; Prausnitz, Langer, 2009; Alexander et al., 2012).

Many drug products applied to the skin surface may penetrate to some extent into the skin layers, where

*Correspondence: G. R. Pereira. Departamento de Alimentos e Medicamentos. Faculdade de Ciências Farmacêuticas Universidade Federal de Alfenas. Rua Gabriel Monteiro da Silva, 700, 37130-001 - Alfenas- MG, Brazil. E-mail: gislaine.pereira@unifal-mg.edu.br their effects are expected. This is the case for topical formulations for treatment of skin disorders such as acne and cutaneous inflammatory diseases that include dermatitis, erythematous lupus, and psoriasis. On the other hand, transdermal formulations release drugs that permeate through the skin and enter the systemic circulation. Transdermal therapy must ensure that significant concentrations of the drug are absorbed to reach effective plasma concentrations. Permeation of drugs is targeted in some cases to body regions close to the action site, where a regional effect is expected, e.g., in the muscles, blood vessels, and articulations. In this way, the term "cutaneous absorption" is properly used to characterize the sum of the amounts of drug that penetrate and permeate the skin (Barry, 2001; El Maghraby, Barry; Williams, 2008; Williams, Barry, 2012; Selzer et al., 2013).

Different methods have been proposed to evaluate the cutaneous absorption of drugs to optimize the development of novel formulations to be administered 
through the skin. These methods are important tools for assessing the efficacy and quality of topical and transdermal formulations (Lin, Ho, Chien, 1993; Manadas, Pina, Veiga, 2002; Thakker, Chern, 2003; Valenta, Auner, 2004; Cardot, Beyssac, Alric, 2007; Frum et al., 2007; Chen, Han, Lian, 2013; Schwarz, Pagitsch, Valenta, 2013). However, pharmaceutical formulation scientists must be aware of all options in the selection of methods for intended formulations (Seki et al., 2004; Godin, Touitou, 2007; Zhang, Chan, Leong, 2013).

The aim of this study was to systematically review the in vitro and in vivo methods applied to the assessment of skin penetration and permeation of drugs from topical and transdermal formulations, with the goal of aiding the pharmaceutical formulation scientists in the selection of the most appropriate formulation for a particular investigation.

\section{Drug transport across the skin}

The skin is the largest organ of the human body and has a surface area of about $2 \mathrm{~m}^{2}$ in healthy adults (Groeber et al., 2011). It is a heterogeneous multilayer tissue, and its primary function is to protect the body from the external environment by functioning as an effective barrier to absorption of exogenous molecules (Godin, Touitou, 2007; Darlenski et al., 2009; Prausnitz, Langer, 2009; Williams, Barry, 2012; Anissimov et al., 2013; Jepps et al., 2013). The epidermis and dermis layers form the main skin structure (Figure 1).

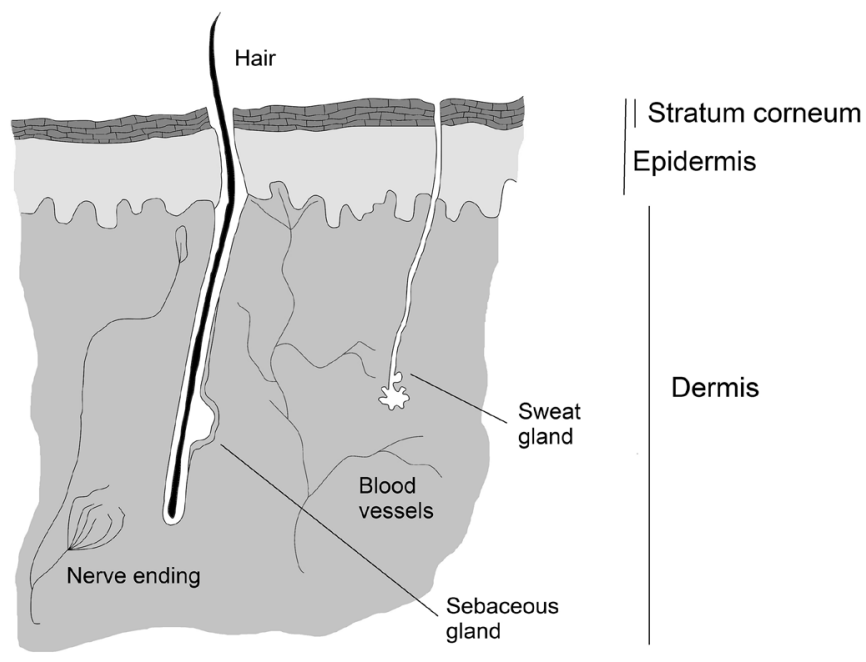

FIGURE 1 - Normal human skin.

The dermis thickness ranges from 3 to $5 \mathrm{~mm}$ and consists of a mixture of fibrous proteins (collagen and elastin) and an interfibrillar gel of glycosaminoglycans, salts, and water. Collagen types I and II account for approximately $75 \%$ of the dry weight of the dermis. Blood and lymph vessels, free nerve endings, hair follicles, and sebaceous and sweat glands are embedded in the dermis. The hair follicles and sweat gland ducts open directly to the outside on the surface of the skin (Caspers et al., 1998; Moser et al., 2001; El Maghraby, Barry, Williams, 2008; Cevc, Vierl, 2010; Notman, Anwar, 2013; Mathes, Ruffner, Graf-Hausner, 2014).

The epidermis, excluding the stratum corneum, which is its outermost layer, is a viable tissue. The epidermis does not have vascularization, and nutrients diffuse from the dermoepidermal junction to maintain its viability. There are five layers that represent the different stages of cell life in the epidermis. The sequence of layers from inside to outside are the germinative (or basal) layer, stratum spinosum, stratum granulosum, stratum lucidum, and stratum corneum (Karadzovska et al., 2013; Notman, Anwar, 2013; Mathes, Ruffner, Graf-Hausner, 2014).

The stratum corneum cells are called corneocytes. These cells are dense, functionally dead, anucleated, and filled with keratin. The stratum corneum arrangement is analogous to a wall of "bricks and mortar" in that corneocytes represent the bricks and the intercellular lipids represent the mortar. The lipids form several bilayers surrounding the corneocytes. The intercellular lipid consists of a mixture of ceramides, cholesterol, cholesterol esters, fatty acids, and a small fraction of cholesterol sulfate (Barry, 2001; EL Maghraby, Barry, Williams, 2008; Anissimov et al., 2013; Jepps et al., 2013). The stratum corneum contains 15 to 20 layers of corneocytes, and, in its dry state, has a thickness of 10 to $15 \mu \mathrm{m}$. When hydrated, the stratum corneum considerably swells, and its thickness may reach up to 40 $\mu \mathrm{m}$, showing an increased permeability. Considering its barrier characteristics and water resistance, the stratum corneum is the main layer that limits drug absorption through the skin (El Maghraby, Barry, Williams, 2008; Cevc, Vierl, 2010; Anissimov et al., 2013; Jepps et al., 2013). Andrews and co-workers (2013) observed that removal of the stratum corneum drastically increased skin permeability, whereas removal of the full epidermis increased skin permeability by 1 to 2 orders of magnitude. Therefore, different skin layers influence permeability but at different magnitudes.

The skin permeation routes include transport across the epidermis and skin appendages, particularly the hair follicles and sweat glands that form an alternative pathway to the intact epidermis. The skin appendages represent only $0.1 \%$ of the total surface of the human skin and the contribution of this route for permeation 
flux of drugs is small. Recently, it was proposed that the route through the skin appendages contributes little to the rate of skin absorption of most drugs in the steady state; however, this route enables permeation of charged molecules and large polar compounds; e.g., peptide-based drugs. The major route of skin permeation is through the intact epidermis, and two main pathways have been identified: the intercellular route through the lipids of the stratum corneum and the transcellular route through the corneocytes. In both cases, the drug must diffuse into the intercellular lipid matrix, which is recognized as the major determinant of drug absorption by the skin (Alexander et al., 2012; Desai et al., 2013; Frasch, Barbero, 2013; Notman, Anwar, 2013).

According to Kalia and Guy (2001), drug transport in the skin is a process involving several steps: $a$ ) dissolution and release of drug from the formulation; $b$ ) drug partitioning into the stratum corneum; c) drug diffusion across the stratum corneum, mainly by intercellular lipids; d) drug partitioning from the stratum corneum into viable epidermis layers; $e$ ) diffusion across the viable epidermis layers into the dermis, and f) drug absorption by capillary vessels, which achieves systemic circulation (Kalia, Guy, 2001).

The choice of drug candidates for permeation through the skin must be based on several factors, including physicochemical properties, drug interactions with the membrane, and pharmacokinetic considerations. The ideal physicochemical properties of a drug selected for cutaneous administration are low molecular weight $(<600 \mathrm{Da})$ because the diffusion coefficient will be high; solubility in water and oils to achieve a high concentration gradient and increase the diffusion force across the skin; an elevated but balanced partition coefficient because very high partition coefficients may inhibit drug clearance from the skin and increase drug retention; and a low melting point $\left(<200{ }^{\circ} \mathrm{C}\right)$, which is related to an appropriate solubility (Kalia, Guy, 2001; Moser et al., 2001; Farahmand, Maibach, 2009; Williams, Barry, 2012; Delgado-Charro, Guy, 2014).

\section{In vitro evaluation of the skin permeation of drugs}

In vitro methods enable precise control of experimental variables by using the simplest protocols. However, in vitro assays cannot fully reproduce the complexity of biological systems, and in vivo evaluations are recommended to validate the results and, if possible, establish an in vivo-in vitro correlation. Nevertheless, in vitro evaluations are essential tools for the development and screening of formulations, predicting in vivo cutaneous absorption (Thakker, Chern, 2003; Cardot, Beyssac, Alric, 2007; Frum et al., 2007; Godin, Touitou, 2007; Yang et al., 2015).

The diffusion cell is the most widely used experimental apparatus to assess the release and skin permeation of drugs incorporated in topical and transdermal drug delivery systems. The main objective of these assessments lies in identifying the main variables during formulation design that may alter the in vivo bioavailability of the drug (Lewis, Paulo, Faustino, 1997; Brown et al., 2004; Godin, Touitou, 2007; Cevc, Vierl, 2010; Hanson, 2010). The first work in this field was developed by Thomas J. Franz in 1970. The basic configuration of the experimental apparatus is composed of a) the donor compartment, wherein the formulation is applied to a semipermeable membrane where the drug released must permeate, and b) a receiver chamber, wherein samples can be withdrawn for drug analysis (Moser et al., 2001; Leveque et al., 2004; Hanson, 2010).

The vertical diffusion cell is a modification of the original Franz diffusion cell. This apparatus has been used to evaluate different formulations, such as gels, creams, ointments, and patches (Thakker, Chern, 2003; Hanson, 2010). Different configurations of this diffusion cell are commercially available and have different volume capacities in the receiver chamber $(4,7$, and $12 \mathrm{~mL})$ and effective diffusion areas $\left(1.77\right.$ and $\left.2.54 \mathrm{~cm}^{2}\right)$. The scheme of the vertical diffusion cell is shown in Figure 2.

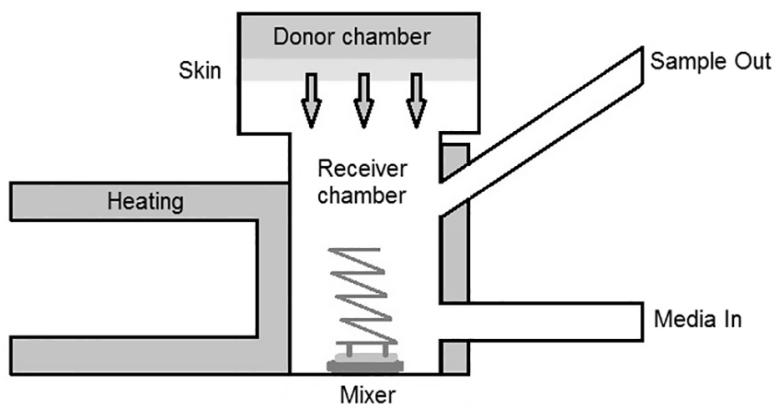

FIGURE 2 -Vertical diffusion cell (Reproduced with permission from Wiley-Scrivener from Ruela, Pereira, 2017).

The experimental conditions for assessment of skin permeation include a receptor medium maintained under constant magnetic stirring and temperature. Important considerations must be highlighted; e.g., the composition of the medium must assure sink conditions because the drug concentration must not reach values $>10 \%$ of its saturation (Azarmi, Roa, Löbenberg, 2007). For this, the drug must be freely soluble in the receptor medium. The sink conditions are an essential presupposition so that the 
drug concentration in the receptor medium does not limit the permeation rate. The recommended receptor media are aqueous buffers related to the physiological environment. The use of additives in the receptor medium is necessary in some cases to increase the drug's solubility, but these additives should not compromise the integrity of the membrane or alter the drug's permeability. Some additives incorporated in the medium are non-ionic surfactants (e.g., Tween 80 ), bovine serum albumin, polyethylene glycol, and ethanol. To prevent microbiological growth in the medium, preservatives may be added, such as gentamicin, sodium azide $(0.02 \%-0.05 \%)$ and formaldehyde $(0.1 \%)$. Selective analytical techniques are used for appropriate separation of contaminants from the skin, formulation, or receptor medium. High-performance liquid chromatography (HPLC) is recommended for drug quantification (Siewert et al., 2003; Thakker, Chern, 2003; Wang, Ma, Higgins, 2006; Hanson, 2010; Ruela et al., 2013; Selzer et al., 2013).

The Keshary-Chien cell is an experimental apparatus for evaluation of poorly water-soluble drugs, which assures sink conditions. The apparatus has the same configuration as that of the vertical diffusion cell; however, it can increase the homogeneity of larger volumes $(>15$ $\mathrm{mL}$ ) of the receptor medium (Tojo, Keshary, Chien, 1986). The flow-through cell is another experimental apparatus indicated for evaluation of poorly water-soluble drugs. In this apparatus, the medium is perfused in a constant flow rate by using a peristaltic pump. The flow-through cell is usually applied to assure sink conditions, but drug dilution in the receptor medium may require a sensible analytical method for its quantification (Gupta, Jain, Varshney, 2005; Choi et al., 2012; Selzer et al., 2013).

The diffusion cell can be modified to evaluate transdermal formulations on the basis of iontophoresis. Iontophoresis is a physical process for enhancing drug permeation through the skin by applying an electric field. The diffusion cells are adapted with silver-silver chloride electrodes in the donor chamber for application of a current on the skin surface. The formulations are prepared in an aqueous vehicle, such as hydrogels, and the drug is ionized. The drug diffusion is driven by the electroosmotic flow due to the electric field (Gratieri, Gelfuso, Lopez, 2008; Alexander et al., 2012; Patni et al., 2012; Gratieri, Kalia, 2013; Saluja et al., 2013).

The United States Pharmacopeia apparatus II (paddle) is less used for evaluating skin permeation of drugs. This assay employs a glass cylindrical tube closed on one side of its border with excised skin, with stratum corneum inside. The formulation is placed into the cylindrical tube over the, stratum corneum, and the dermis side is submerged into the receptor medium. Samples of the medium are withdrawn at different times for drug quantification (Fouad et al., 2013).

Whole skin or dermatomed tissues have been used for in vitro permeation assays. The dermatomization technique standardizes the thickness of the skin, but it has been associated with increased skin permeations by the follicular route because of the opening of the bottom of the follicles. On the other hand, when the whole skin is used, the dermis layer may take up water because of swelling of this layer. In this case, drug diffusion is decreased and drug retention in the dermis may be increased (Moser et al., 2001; Alexander et al., 2012; Selzer et al., 2013).

The most relevant model for evaluation of in vitro skin absorption of drugs is human skin excised from cadavers or obtained from plastic surgeries. However, the availability of human skin is limited, and animal models are often employed. The skin from animal models is highly recommended for preliminary evaluations in the screening of novel formulations. The animal models used to replace human skin are domestic pigs, rats, mice, guinea pigs, and snakes (Nair et al., 1997; Zorin, Kuylenstierna, Thulin, 1999; Nair et al., 2013). According to Godin and Touitou (2007), the porcine ear skin has shown results comparable to those of normal human skin (Godin, Touitou, 2007). Studies examining the thickness of various skin layers have shown that pig ear skin has a thickness similar to that of human skin (stratum corneum and epidermis). The follicular structure, vascular anatomy, and arrangement of collagen fibers in the dermis of the pig ear, as well as the content of glycosphingolipids and ceramides, are also similar to those of the human skin (Nair et al., 1997; Zorin, Kuylenstierna, Thulin, 1999; Heard et al., 2006; Klang et al., 2012; Chen, Han, Lian, 2013; Delgado-Charro, Guy, 2014).

Skin permeation studies using inadequate protocols generate inaccurate data (Godin, Touitou, 2007). Thus, selection of the protocol must be performed by using experimental conditions, such as skin model, experimental apparatus, and receptor medium, appropriate for the formulation to be evaluated, and it must be based on the physicochemical properties of the drug, including aqueous solubility and oil-water partition coefficients. Several recent studies have focused on development of transdermal devices for administration of donepezil, an anti-Alzheimer drug (Choi et al., 2012; Subedi et al., 2012; Saluja et al., 2013; Liu et al., 2014). In these studies, the permeation of this lipophilic compound $(\log \mathrm{P}>4)$ was studied by using different experimental protocols, including skin models, experimental apparati, and formulations. Choi and co- 
workers (2012) demonstrated a 1-fold reduction in the results of donepezil permeation by using human cadaver skin relative to the results of studies using hairless mouse skin, a skin model with increased permeability. The permeation of donepezil was also studied by Liu et al. (2014) who used rabbit abdominal skin and by Subedi and co-workers (2012) who used isolated hairless mouse skin. These authors also achieved satisfactory results by using these skin models; however, the amounts of drug permeated were overestimated in relationship to permeation across normal human skin. Different experimental apparati were applied with satisfactory results to evaluate the skin permeation of donepezil from different formulations, including the Keshary-Chien cell (Choi et al., 2012) and flow-through cell (Subedi et al., 2012). In all cases, an important point is to perform in vitro screening of drug permeation from different formulations and identify the factors that increase the transdermal flux of the drugs to predict their in vivo behavior from different drug delivery systems.

Some experimental conditions for studying in vitro skin permeation were selected and are shown in the Table I. There was a huge number of experimental conditions in the selected studies using skin permeation assays, including the skin model, composition of receptor medium, and type of diffusion cell. Comparison of skin permeation data from different studies is not a simple task, and permeation data must be analyzed to determine the effects of the formulations under the same experimental conditions. In this way, it is possible to identify the variables in formulations that increase drug flux through the skin as a way to select promising formulations for evaluation in clinical trials.

For analysis of the permeation data, the amounts of drug permeated are plotted against the time. In many cases, an excess of drug is applied to the skin surface (infinite dose), and its depletion is negligible. In these cases, drug permeation follows zero-order kinetics, which characterizes the drug diffusion across the skin according to Fick's law. In these cases, a linear equation is calculated in the steady state, and its inclination represents the flux of drug across the skin, also denominated as the permeation rate. In contrast, when a finite dose of drug is applied to the skin, the relationship between amounts of drug permeated and time is not linear. When the drug amounts applied to the skin decrease along the time, the permeation rate is also decreased. Drug flux through the skin under non-saturated conditions follows pseudo-zero order kinetics (or Higuchi kinetics), in which the drug concentration is proportional to the square root of time (Moser et al., 2001; Selzer et al., 2013).

\section{Evaluating the penetration of drugs into the skin}

The evaluation of penetration of drugs into the skin is important in development of topical formulations because the expected effect is targeted to the superficial layers of the skin. The concentrations of drug in the skin layers can be determined by in vitro and in vivo assays, such as by conducting cutaneous retention studies and by using the tape-stripping technique (Moser et al., 2001; Yamashita, Hashida, 2003; Naegel, Heisig, Wittum, 2013; Nair et al., 2013; Selzer et al., 2013).

\section{Tape-stripping technique}

The tape-stripping technique is applied in vitro for analyses of drug penetration into the stratum corneum. The procedure may be applied in vivo using animal models or human volunteers, once that it is minimally invasive and painful. This technique has also been applied to assess the potential toxicity of bioactive compounds absorbed by the stratum corneum (Klang et al., 2012; Selzer et al., 2013; Paleco et al., 2014).

The tape-stripping technique involves sequential removal of cell layers of the stratum corneum by application of pieces of adhesive tape. The residues of the formulation are previously removed from the skin surface, and the tape is applied by using pressure to ensure its adhesion to the skin. When the tape is removed, a portion of the stratum corneum is also removed. The first piece of tape is discarded to eliminate the residues of the formulation. The other pieces of tape are sequentially applied (mean of 16 applications) to strip the skin on the site where the formulation was administered. The pressure and speed of application should be the same during the entire process to assure the homogeneity of the relative amount of stratum corneum removed. The pieces of the tape are collected, and drug extraction is performed by using solvents. The solvents are selected on the basis of the drug solubility. The samples are stirred and centrifuged, and the drug is recovered in the supernatant. Validation studies are performed by using spiked tapes with known drug concentrations for determination of the percentage of recovery. The dermatopharmacokinetic studies of the drug may be performed in vivo by tape-stripping to evaluate the bioavailability of drugs from topical formulations (hydrogels, creams, and ointments) (Nair et al., 1997; Moser et al., 2001; Yamashita, Hashida, 2003; Anissimov et al., 2013; Selzer et al., 2013).

Matos et al. (2015) performed an interesting tapestripping procedure of the porcine ear skin after the administration of nanoparticles containing minoxidil, 
TABLE I - Some experimental conditions used for evaluation of in vitro skin permeation of drugs

\begin{tabular}{|c|c|c|c|c|c|}
\hline $\operatorname{Drug}\left(\log P^{a}\right)$ & Skin model & $\begin{array}{c}\text { Receptor medium/ } \\
\text { Temperature/Stirring }\end{array}$ & Diffusion cell type & Studied time & Reference \\
\hline $\begin{array}{l}\text { Testosterone } \\
(\log \mathrm{P}=3.47)\end{array}$ & Rat skin & $\begin{array}{c}\text { Saline }+40 \% \\
\text { Polyethylene glycol } \\
400 / 37^{\circ} \mathrm{C}^{-\mathrm{NI}^{\mathrm{c}}}\end{array}$ & Keshary-Chien & $26 \mathrm{~h}$ & Kim et al., 2001 \\
\hline $\begin{array}{l}\text { Oxybutynin } \\
(\log \mathrm{P}=5.19)\end{array}$ & Rabbit ear skin & $0.9 \%$ Saline $/ 37^{\circ} \mathrm{C} / \mathrm{NI}^{\mathrm{c}}$ & Franz & $8 \mathrm{~h}$ & Nicoli et al., 2006 \\
\hline $\begin{array}{l}\text { Valsartan } \\
(\log P=4.75)\end{array}$ & $\begin{array}{l}\text { Rat and hairless } \\
\text { mice skin, skin of } \\
\text { Yucatan micropig } \\
\text { (dermatomated) }\end{array}$ & $\begin{array}{c}\mathrm{PBS}^{\mathrm{b}} \mathrm{pH} 7.4 / 37^{\circ} \mathrm{C} / \\
600 \mathrm{rpm}\end{array}$ & Vertical & $\begin{array}{c}8 \mathrm{~h} \text { for drug } \\
\text { suspensions, } \\
\text { and } 48 \mathrm{~h} \text { for } \\
\text { transdermal } \\
\text { patches }\end{array}$ & Nishida et al., 2010 \\
\hline $\begin{array}{l}\text { Ondansetron } \\
(\log P=2.07)\end{array}$ & Hairless mice skin & $\mathrm{PBS}^{\mathrm{b}} \mathrm{pH} 7.4 / 37^{\circ} \mathrm{C} / \mathrm{NI}^{\mathrm{c}}$ & Franz & $\mathrm{NI}^{\mathrm{c}}$ & Obata et al., 2010 \\
\hline $\begin{array}{l}\text { Nicotine } \\
(\log P=0.72)\end{array}$ & $\begin{array}{l}\text { Human skin } \\
\text { (200 } \mu \mathrm{m}, \\
\text { dermatomated })\end{array}$ & Saline $0.9 \% / 37^{\circ} \mathrm{C} / \mathrm{NI}^{\mathrm{c}}$ & $\begin{array}{c}\text { Diffusion cell } \\
\text { modified with } \\
\text { silver-silver } \\
\text { chloride electrode }\end{array}$ & $\mathrm{NI}^{\mathrm{b}}$ & Wu et al., 2010 \\
\hline
\end{tabular}

\begin{tabular}{|c|c|c|c|c|c|}
\hline $\begin{array}{l}\text { Theophylline } \\
(\log P=-0.17) \text { and } \\
\text { hydrocortisone } \\
(\log P=1.43)\end{array}$ & Porcine ear skin & $\begin{array}{l}\mathrm{PBS}^{\mathrm{b}} \mathrm{pH} 7.4+0.03 \% \\
\quad \text { of sodium azide } \\
\text { (preservative) } / 32^{\circ} \mathrm{C} / \mathrm{NI}^{\mathrm{c}}\end{array}$ & Franz & $\begin{array}{c}48 \mathrm{~h} \\
\text { (theophylline) } \\
\text { and } 52 \mathrm{~h} \\
\text { (hydrocortisone) }\end{array}$ & Novotný et al., 2011 \\
\hline $\begin{array}{l}\text { Diclofenac sodium } \\
(\log P=4.06)\end{array}$ & $\begin{array}{l}\text { Human skin (only } \\
\text { epidermis) }\end{array}$ & $\begin{array}{c}\mathrm{PBS}^{\mathrm{b}} \mathrm{pH} 7.4+2.5 \% \\
\text { hydroxypropyl- } \beta- \\
\text { cyclodextrin/NI } / 400 \mathrm{rpm}\end{array}$ & Franz & $\mathrm{NI}^{\mathrm{b}}$ & $\begin{array}{l}\text { Snorradóttir et al., } \\
2011\end{array}$ \\
\hline $\begin{array}{l}\text { Donepezil } \\
(\log P=4.71)\end{array}$ & $\begin{array}{l}\text { Hairless mice and } \\
\text { human skin }\end{array}$ & $\begin{array}{c}\mathrm{PBS}^{\mathrm{b}} \mathrm{pH} 7.4 / 32^{\circ} \mathrm{C} / \\
600 \mathrm{rpm}\end{array}$ & Keshary-Chien & $12 \mathrm{~h}$ & Choi et al., 2012 \\
\hline $\begin{array}{l}\text { Timolol } \\
(\log \mathrm{P}=0.68)\end{array}$ & $\begin{array}{l}\text { Guinea pig skin and } \\
\text { human skin }\end{array}$ & $\begin{array}{l}\text { Phosphate buffer } \mathrm{pH} \\
7.4 / 37^{\circ} \mathrm{C} / 600 \mathrm{rpm}\end{array}$ & $\begin{array}{l}\text { Keshary-Chien } \\
\text { modified with } \\
\text { silver-silver } \\
\text { chloride electrode }\end{array}$ & $7 \mathrm{~h}$ & Patni et al., 2012 \\
\hline $\begin{array}{l}\text { Donepezil } \\
(\log \mathrm{P}=4.71)\end{array}$ & Hairless mice skin & Buffer $\mathrm{pH} 6.0 / 37^{\circ} \mathrm{C} / \mathrm{NI}^{\mathrm{c}}$ & Flow-through cell & $24 \mathrm{~h}$ & Subedi et al., 2012 \\
\hline $\begin{array}{l}\text { Theophylline } \\
(\log \mathrm{P}=-0.17) \text { and } \\
\text { hydrocortisone } \\
(\log \mathrm{P}=1.43)\end{array}$ & Porcine ear skin & $\begin{array}{l}\mathrm{PBS}^{\mathrm{b}} \mathrm{pH} 7.4+0.03 \% \\
\text { of sodium azide } \\
\text { (preservative) } / 32^{\circ} \mathrm{C} / \mathrm{NI}^{\mathrm{c}}\end{array}$ & Franz & $\begin{array}{c}48 \mathrm{~h} \\
\text { (theophylline) } \\
\text { and } 52 \mathrm{~h} \\
\text { (hydrocortisone) }\end{array}$ & Janůšová et al., 2013 \\
\hline $\begin{array}{l}\text { Fluoxetine } \\
(\log P=4.09)\end{array}$ & $\begin{array}{l}\text { Hairless mice, rat } \\
\text { and human skin }\end{array}$ & 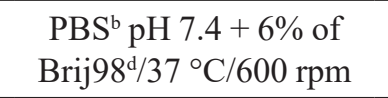 & Keshary-Chien & $12 \mathrm{~h}$ & Jung et al., 2013 \\
\hline $\begin{array}{l}\text { Nicotine } \\
(\log P=0.72)\end{array}$ & Porcine ear skin & $\begin{array}{c}\mathrm{PBS}^{\mathrm{b}} \mathrm{pH} 7.4 / 32^{\circ} \mathrm{C} / \\
600 \mathrm{rpm}\end{array}$ & Vertical & $48 \mathrm{~h}$ & $\begin{array}{l}\text { Ruela et al., 2013; } \\
\text { Ruela, Figueiredo, } \\
\text { Pereira, } 2014\end{array}$ \\
\hline $\begin{array}{l}\text { Isosorbide dinitrate } \\
(\log \mathrm{P}=-0.90)\end{array}$ & Hairless rat skin & $\begin{array}{c}\text { Saline }+ \\
\text { Polyethyleneglycol } \\
400 / 37^{\circ} \mathrm{C} / 200 \mathrm{rpm}\end{array}$ & Franz & $24 \mathrm{~h}$ & Zhan et al., 2015 \\
\hline
\end{tabular}

${ }^{\mathrm{a}} \mathrm{ACD} / \mathrm{Log}$ P values from www.chemspider.com (Royal Society of Chemistry); ${ }^{\mathrm{b} B S}$, phosphate-buffered saline; ${ }^{\mathrm{C} N I}$, not informed; 'Brij98, polyoxyethylene(20) oleyl ether. 
analyzing the retention of this drug in the stratum corneum and follicular casts. Analysis of the drug retained in the stratum corneum was performed by using the conventional tape-stripping technique, and analysis of the drug retained in the follicular casts was performed by application of cyanoacrylate glue to the stripped skin, which was covered with a tape strip. After the glue was polymerized by exposure to ultraviolet light, the tape strip was removed, and the drug in the follicular casts was recovered from the glue and analyzed by HPLC. Similar results of differential stripping combined with other techniques were previously obtained by Desai et al. (2013), which demonstrated that percutaneous permeation pathways (follicular or nonfollicular) may be studied after topical administration of drugs.

In general, some considerations must be taken before the tape-stripping procedure. The application site should be uniform and without skin damage. The adhesive tapes can be purchased from different manufacturers, but they must be compatible with the solvent used for drug extraction. The tapes with acrylic or silicone adhesives are widely used for this purpose. Moreover, the tape must be innocuous and does not cause allergic reactions or inflammation in the skin (Haag et al., 2011; Klang et al., 2012).

Recent advances in the tape-stripping technique were achieved by its combination with other techniques, such as attenuated total reflectance Fourier-transform infrared (ATR-FTIR) and confocal laser scanning microscopy. These approaches will be discussed in the following sections.

\section{Studies of cutaneous retention}

Cutaneous retention of drugs and other bioactive compounds can be assessed by direct measurements of drug concentration in the whole skin and skin layers previously isolated or by using reconstructed skin models. The skin layers can be isolated by using several techniques. The dermis and epidermis are separated by immersing the skin in heated water $\left(60^{\circ} \mathrm{C}\right)$ for 1 minute. Next, the epidermis is detached from the dermis. The stratum corneum also can be isolated by immersing the whole skin in a trypsin solution at $37^{\circ} \mathrm{C}$ for $24 \mathrm{~h}$. After digestion of the skin by an enzymatic solution, only the stratum corneum is recovered (Snorradóttir et al., 2011; Mcauley et al., 2013; Wang et al., 2014).

Experimental protocols are based on in vitro and in vivo evaluations of skin penetration. These evaluations may be performed in vitro after the skin permeation assays using diffusion cells (Reid et al., 2013, Ruela et al., 2013;
Paleco et al., 2014; Shah et al., 2015). Animal models (mice or rats) have been employed for in vivo evaluations. These evaluations must be based on protocols previously approved by an ethics committee. In these cases, the formulations are administered to the skin of the animal, and after a predetermined time interval, the animals are euthanized and the site of application is surgically removed for analysis of drug retained in the skin (Lopes et al., 2006; Vicentini et al., 2008). For drug analysis, the skin is cut into small pieces that are vortexed in a solvent for drug extraction. The skin tissue may also be homogenized by using an Ultra-Turrax type homogenizer. Drug quantification is performed by using selective and validated analytical methods. In general, HPLC is the analytical technique usually employed (Ruela et al., 2013).

Presently, there is a trend in replacement methods for animal experimentation, and $3 \mathrm{D}$ in vitro reconstructed human skin models are alternatives to animal testing (Gotz et al., 2012; Dos Santos et al., 2015). Three-dimensional (3D) in vitro skin models have been employed in both academic and research laboratories of skin-related industries to evaluate the toxicity and efficacy of drugs, drug products, and cosmetics and to study interactions between skin and its microbiome (Bojar, 2015; Dos Santos et al., 2015). Commercial skin substitutes based on keratinocytes and human fibroblasts are available and are recommended for testing skin irritation and skin corrosion (Groeber et al., 2011). Despite the significant value of these skin models for screening drugs and drug products, there are some limitations of $3 \mathrm{D}$ in vitro skin models because they cannot provide a more complex environment of the full thickness of the normal adult skin. $3 \mathrm{D}$ in vitro skin models are usually reconstructed from primary adult human fibroblast and keratinocytes, without incorporation of melanocytes and Langerhans's cells, which require complex nutritional and physical requirements for each cell type (Groeber et al., 2011; Gotz et al., 2012; Bojar, 2015; Dos Santos et al., 2015). In vitro skin substitutes have not yet achieved appreciable application in evaluations of drug skin permeation. However, tissue engineering has shown potential for the development of more complex $3 \mathrm{D}$ in vitro skin models to substitute excised skin from animals, including disease skin models, such as psoriasis, and in vitro infection models, such as herpes models, papilloma viruses, and Candida albicans (Groeber et al., 2011; Bojar, 2015).

\section{In vivo evaluation of the skin permeation of drugs}

Evaluation of in vivo skin absorption is performed by conducting pharmacokinetic studies or alternatively 
by using cutaneous microdialysis. In both cases, these evaluations have been performed with human volunteers or animal models and protocols previously approved by an ethics committee.

\section{Preclinical pharmacokinetic evaluations}

Preclinical pharmacokinetic evaluations with animal models precede clinical trials with human volunteers. The aim of these investigations is to determine if the target plasma concentrations of the drug are achieved or sustained for prolonged periods after administration of the transdermal formulation. In many cases, in vivo-vitro correlations are determined from the in vitro skin permeation data (Lin, Ho, Chien, 1993; Wilding et al., 1996; Costa, Sousa Lobo, 2001; Zhao et al., 2006; Farahmand, Maibach, 2009; Ren et al., 2009).

In general, the pharmacokinetic evaluations use plasma concentrations of the drug. For this, blood samples are collected at different times after administration of the transdermal delivery system. Plasma is separated immediately by centrifugation, and the drug is extracted and analyzed by using a selective analytical method, such as HPLC or gas chromatography. In many cases, the use of chromatographic techniques coupled with mass spectrometry is necessary. The pharmacokinetic parameters are determined from a plot of drug plasma concentrations versus time. The recommended parameters to be calculated are the area under the curve, the peak plasma concentration of the drug, and the time needed to reach the maximum. Drug concentration in the steady state and the lag time may be also determined. Rat models are generally used in these studies (hairless, Wistar, or Sprague-Dawley). The transdermal formulation is administered in the dorsal or abdominal regions of the animals (Kim et al., 2001; Nishida et al., 2010; Yang et al., 2012; Jung et al., 2013). Beagle dogs and guinea pigs are selected in some studies (Ye et al., 2008; Chen et al., 2013). Although these preclinical evaluations are important, the results cannot be extrapolated to humans if the selected animal models show significant differences in skin permeability, drug metabolism, and elimination (Choi et al., 2012; Jung et al., 2013).

Hair removal at the site of application may be necessary before the administration of transdermal formulations in animal models and can be done by using a clipper or depilatory creams (Gupta et al., 1993; Nishida et al., 2010; Choi et al., 2012; Saluja et al., 2013). The integrity of the skin permeability must be assured. Transepidermal water loss from the skin or electrical conductivity measurements across the skin are useful for detection of skin damage, physical injury, or pathological conditions. The toxicity of the drug or formulation in the skin also may be investigated (Ashtikar et al., 2013; Pažoureková et al., 2013; Oliveira et al., 2014; Guth et al., 2015).

Pharmacokinetic evaluations of a transdermal delivery system are essential to determine the in vivo behavior of the drug administered by the skin route because in vitro studies cannot reproduce the complexity of biological systems, such as metabolism, distribution, and elimination. The contribution of skin absorption by different pathways, such as the epidermis or skin appendages, is also important and may be characterized during the preclinical pharmacokinetic studies (Godin, Touitou, 2007; Farahmand, Maibach, 2009).

\section{Cutaneous microdialysis}

In vivo evaluations using cutaneous microdialysis have been used for quantification of cerebral neurotransmitters (Shearman et al., 2006; Cerbai et al., 2007; Shannon et al., 2013), glucose monitoring in diabetes mellitus (Mader et al., 2012), measurement of antibiotics levels (Roberts et al., 2008; K. Hurtado et al., 2014), and measurement of antineoplastic drug levels in the target tissue (Höcht, Opezzo, Taira, 2007). Among these applications, the assessment of in vivo skin absorption of drugs from topical and transdermal formulations has also been described (Schnetz, Fartasch, 2001; Kreilgaard, 2002; Brunner, Derendorf, 2006). Although the traditional pharmacokinetic evaluations assess the total drug in the sample (drug-protein binding and free drug fraction), this technique measures only the free drug fraction directly in the target tissue (Nakashima et al., 2006; Shearman et al., 2006; Zhang et al., 2007; Shinkai et al., 2011).

Cutaneous microdialysis is classified as a semiinvasive technique in which a semipermeable microdialysis probe is inserted into defined skin layers (epidermis or dermis), directly under the formulation (Figure 3 ). The physiological solution (saline or Ringer's solution) is slowly perfused by using a pump $(1-10 \mu \mathrm{L} / \mathrm{min})$. The compounds in the tissue interstitial fluid diffuse into the dialysate in the probe. The samples are free of proteins and other macromolecules because of the molecular weight cutoff of the semipermeable membranes (20-100 kDa). The dialysate is collected at different times, and the drug is directly analyzed by for example, HPLC. However, in some cases, because of the small amounts of sample (a few microliters) and the drug dilution, high sensitivity 


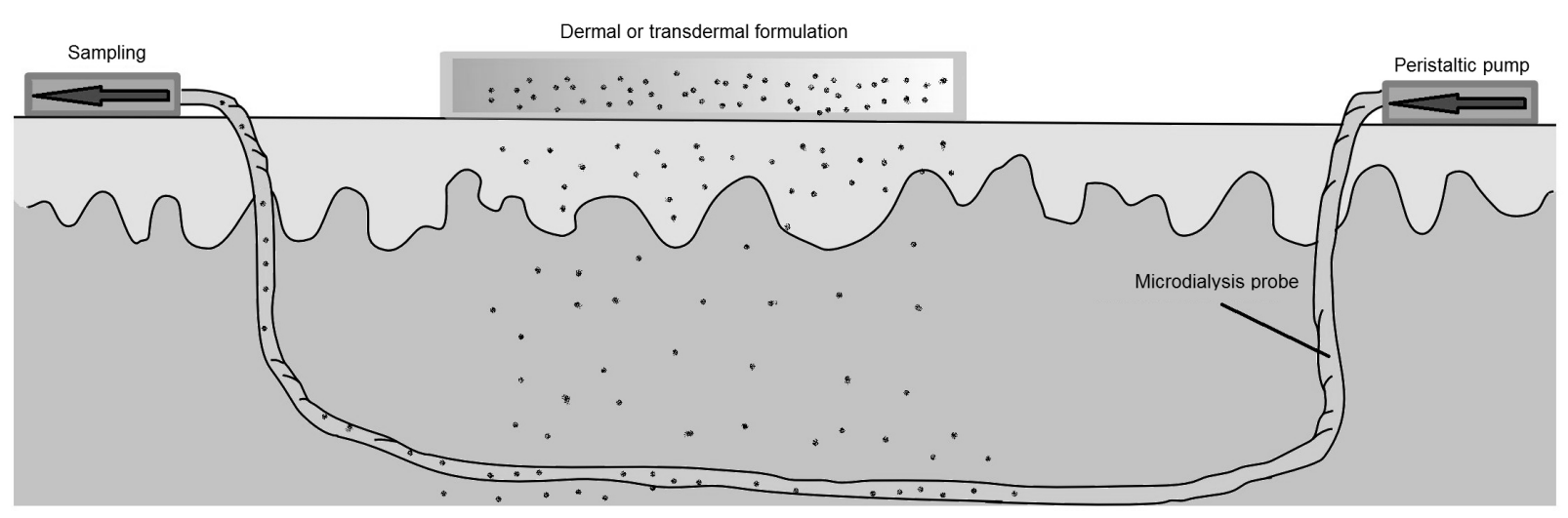

FIGURE 3 - Cutaneous microdialysis.

analytical techniques, such as HPLC coupled with mass spectrometry, are required (Kreilgaard, 2002; Tang et al., 2013).

The recovery of drug from the dialysate is an important parameter to be determined. The relative recovery of the drug is evaluated by using the retrodialysis technique. For these evaluations, a drug solution with known concentration is perfused for a defined time. Next, the drug concentration in the dialysate is determined (Kreilgaard, 2002; Brunner, Derendorf, 2006; Shinkai et al., 2011). The initial $\left(\mathrm{C}_{\text {initial }}\right)$ and final $\left(\mathrm{C}_{\text {final }}\right)$ concentrations are used in the determination of the relative recovery according to the Equation (1):

$$
\operatorname{Recovery}(\%)=100-\frac{100 \times C_{\text {final }}}{C_{\text {initial }}}
$$

Cutaneous microdialysis shows better results for recovery of hydrophilic compounds, and some limitations have been reported for evaluation of lipophilic drugs. Once the dialysate is an aqueous solution, the recovery of lipophilic and poorly water-soluble drugs is very low. Compounds with high molecular weights, such as peptides and proteins, cannot be determined by cutaneous microdialysis because of the molecular weight cutoff of the membranes. Overall, the technique is attractive because of its relatively low cost relative to the costs of traditional pharmacokinetic studies (Kreilgaard, 2002; Brunner, Derendorf, 2006).

It also has been reported that cutaneous microdialysis offer advantages in relationship to in vivo tape-stripping for assessment of the bioavailability of drugs from topical formulations (Seki et al., 2004). Although tape-stripping only evaluates drug absorption in the stratum corneum, cutaneous microdialysis evaluates drug absorption in the depth layers of the skin. In these cases, cutaneous microdialysis enables characterization of skin absorption and clearance of drugs from topical formulations (Shinkai et al., 2011; Tang et al., 2013).

Leveque et al. (2004) studied the skin absorption of salicylic acid by using cutaneous microdialysis and compared the results with those from in vitro skin permeation studies using a Franz diffusion cell (Leveque et al., 2004). Even though the major salicylic acid levels were determined by using the microdialysis technique, the results showed good correlation.

Bioequivalence studies of topical formulations may be performed by using cutaneous microdialysis. TetteyAmlalo et al. (2009) evaluated the bioequivalence of ketoprofen gels by using this technique, and the results were compared with those of three different commercial products with satisfactory results (Tettey-Amlalo et al., 2009).

\section{Microscopic and spectroscopic methods applied to the percutaneous absorption of drugs}

Recent advances in the evaluation of percutaneous absorption of drugs were achieved by using microscopic and spectroscopic methods. These new trends in skin absorption studies will be discussed in the following sections.

\section{Attenuated total reflectance fourier-transform infrared spectroscopy}

Attenuated Total Reflectance Fourier-Transform Infrared Spectroscopy (ATR-FTIR) has been applied to studies of the stratum corneum. These studies evaluated modifications in the permeability of the horny layer by using physical methods, treatment with chemical enhancers, examining the array of lipids and the conformation of proteins in the outermost layer of the skin. The displacement of the infrared bands of the 
treated skin relative to those of the untreated skin helped to elucidate the modifications in the stratum corneum caused by chemical or physical treatments (Gupta, Jain, Varshney, 2005; Gannu et al., 2007; Mcauley et al., 2013).

Skin samples are directly placed in a crystal of zinc selenite ( $\mathrm{ZnSe}$ ) without previous treatments (Moser et al., 2001). The bands in the range of $2930-2920 \mathrm{~cm}^{-1}$ and $2855-2850 \mathrm{~cm}^{-1}$ are related to asymmetric and symmetric $\mathrm{CH}_{2}$ stretching that represents the lipid array in the stratum corneum. The lipid matrix of the horny layer has a liquid-crystalline array, and its hexagonal or orthorhombic conformation is related to the frequency of $\mathrm{CH}_{2}$ stretching. The hexagonal array is more fluid than is the orthorhombic one, which indicates increased skin permeability. Complementary information is obtained from angular deformation, such as scissoring of the $\mathrm{CH}$ bond $\left(1454-1466 \mathrm{~cm}^{-1}\right)$. When the hexagonal array is prevalent, just one band of $\mathrm{CH}$ scissoring is visualized; however, when the orthorhombic conformation is prevalent, two bands related to $\mathrm{CH}$ are observed in the same spectral region. The proteins of the stratum corneum also can be characterized by ATR-FTIR. The bands in the $1640-1540 \mathrm{~cm}^{-1}$ range are related to the amine I and II of keratin, and the protein conformation is characterized as a random coil, $\alpha$-helices, or a $\beta$-sheet. Rupture of the secondary structure of proteins ( $\alpha$ or $\beta$ ) leads to the random coil conformation, which increases the skin permeability. The $\alpha$-helices conformation (bands in higher frequencies) forms an array more densely packed than the $\beta$-sheet conformation. In this way, the prevalence of the $\alpha$-helices conformation is indicative of a state of decreased skin permeability (Bernard et al., 2007; Schwarz, Pagitsch, Valenta, 2013; Balázs et al., 2014).

McAuley et al. (2013) studied the effect of fatty acids as chemical enhancers by ATR-FTIR (Mcauley et al., 2013). Cyanophenol was employed as a model molecule because this compound is easily identified in the infrared spectrum by its $\mathrm{CN}$ stretching at $2227 \mathrm{~cm}^{-1}$. The authors studied isolated skin layers (epidermis and stratum corneum) and used ATR-FTIR to characterize the Fickian diffusion of the molecule through the skin.

Wang et al. (2014) studied the effect of polymers based on $\beta$-cyclodextrins as chemical enhancers for transdermal therapy (Wang et al., 2014). ATR-FTIR studies using stratum corneum from mice skin tissues were performed. The effect of the polymers as chemical enhancers was related to modification of the secondary conformation of keratin in the horny layer. Schwarz et al. (2013) performed comparative studies of mucosal membranes (buccal and vaginal) and ear porcine skin by using ATR-FTIR (Schwarz, Pagitsch, Valenta, 2013).
The array of lipids and proteins in the stratum corneum of different tissues was characterized along with the effect of the vehicle (lecithin-based microemulsion) on the skin permeability of flufenamic acid. In this case, the vehicle was prepared by using a deuterated component because the asymmetric and symmetric $\mathrm{CD}_{2}$ stretching were observed in the $2195-2089 \mathrm{~cm}^{-1}$ range, without spectral interference of the skin. The authors employed deuterated phospholipids, and the ATR-FTIR results were compared with those obtained by using the tape-stripping technique. The determination of drug concentrations in the skin layers by using ATR-FTIR did not show satisfactory results because of the attenuation of the infrared signal that depended on the depth in the skin. Under these conditions, the authors observed that the Lambert-Beer law did not show its typical proportionality to drug concentration.

\section{Confocal laser scanning microscopy}

Confocal laser scanning microscopy (CLSM) is a non-invasive technique derived from fluorescence microscopy. Presently, CLSM is a well-established technique for obtaining high-resolution images with depth selectivity. CLSM has been applied in vivo and in vitro to study the skin structure without physically cutting tissue as well as to assess the effects of physical and chemical enhancers on skin permeability. CLSM is also used to diagnose common benign skin lesions and to characterize malignant lesions. Applications of CLSM include the characterization of keratinization and pigmentation disorders (Caspers et al., 2001; Ashtikar et al., 2013; Franzen, Anderski, Windbergs, 2015).

Fluorescent markers, such as fluorescein, Nile red, and 5-bromodeoxyuridine, penetrate the skin, and their skin localization can be characterized by CLSM. These compounds may be incorporated in nanostructured drug delivery systems in which they are encapsulated. The effect of these drug delivery systems can be studied by CLSM to characterize the permeation profiles of these fluorescent markers across the skin or skin appendages. CLSM is based on a laser source that emits a monochromatic beam to excite the fluorescent markers. The fluorescence emitted by the specimen in a single plane is filtered through a dichroic mirror to reach the objective lens, which gives a high-resolution image. The main advantage of CLSM is that it enables characterization of the skin in depth at different focal planes. Thus, the images generated at different planes are combined to obtain a 3D image of the sample (Caspers et al., 1998; Pereira et al., 2002; Das, Agrawal, 2011; Mateus et al., 2013). 
Some limitations of CLSM have been reported and include the limited number of fluorescent markers available for these studies and that only semi-quantitative assessments based on fluorescence signals can be performed. The images are also limited to determined points of the skin at determined times, and the images do not represent the dynamic process of skin permeation for prolonged times (Darlenski et al., 2009; Franzen et al., 2013; Franzen, Anderski, Windbergs, 2015).

\section{Raman confocal microscopy}

Raman spectroscopy is a technique analogous to ATR-FTIR, but it does not suffer from interference by water. Infrared spectroscopy is based on absorption of light, but Raman spectroscopy is based on inelastic scattering of monochromatic light from a laser beam. From the inelastic scattering, the alterations in the wavelength of the photons, which provide a fingerprint by which molecules can be identified in the sample, are analyzed. The excitation or deactivation of molecular vibrations is related to the energetic variations in the photons. Thus, it is possible to obtain detailed information about the chemical structure, electronic configuration, and molecular bonds of a compound. Raman spectroscopy has been applied in different fields as pathology, cosmetics, and pharmaceutical sciences (Caspers et al., 2001; Darlenski et al., 2009).

The association of CLSM and Raman spectroscopy in the last two decades has contributed to the recent advances in the study of skin barrier properties (Caspers et al., 1998; Caspers et al., 2001). This association has led to the development of Raman confocal microscopy (RCM), a non-invasive technique that has the combined advantages of Raman spectroscopy and CLSM (Figure 4) (Baena, Lendl, 2004; Darlenski et al., 2009).
RCM has enabled study of the qualitative biochemical composition of the skin regarding the lipids in the stratum corneum and of natural moisturizing factor components. The thickness of the horny layer and its water concentration also has been determined by RCM. Recent studies using RCM have been conducted to determine the skin absorption of drugs. These studies are limited by signal attenuation in the depth layers of the skin. In the same way as ATR-FTIR signals, refraction index values are altered in the depth layers, and the light scattering becomes more diffuse with increasing skin depth (Franzen et al., 2013).

Mateus et al. (2013) studied the dermatopharmacokinetics of ibuprofen in human volunteers by using RCM and compared the results with those obtained by using the tape-stripping technique (MATES et al., 2013). In both cases, drug diffusion was characterized according to Fick's law. When RCM was employed, relative measurements of drug concentrations in the skin layers were made and compared with the initial amount of drug on the skin surface. This procedure did not allow the precise determination of the drug concentrations in each skin layer.

Franzen et al. (2013) studied mathematical algorithms for correction of the signal attenuation at different skin layers for quantitative analysis of the skin penetration of caffeine (Franzen et al., 2013). For this, the authors created a simulated matrix of keratin, water, and various lipids to obtain a sample with optical properties similar to those of the stratum corneum. The drug was incorporated in the simulated matrix at known concentrations, and the concentrations at different depths were quantitatively determined. The results were promising for quantitative determination of caffeine by using RCM. Recently, the validation of an in vitro method

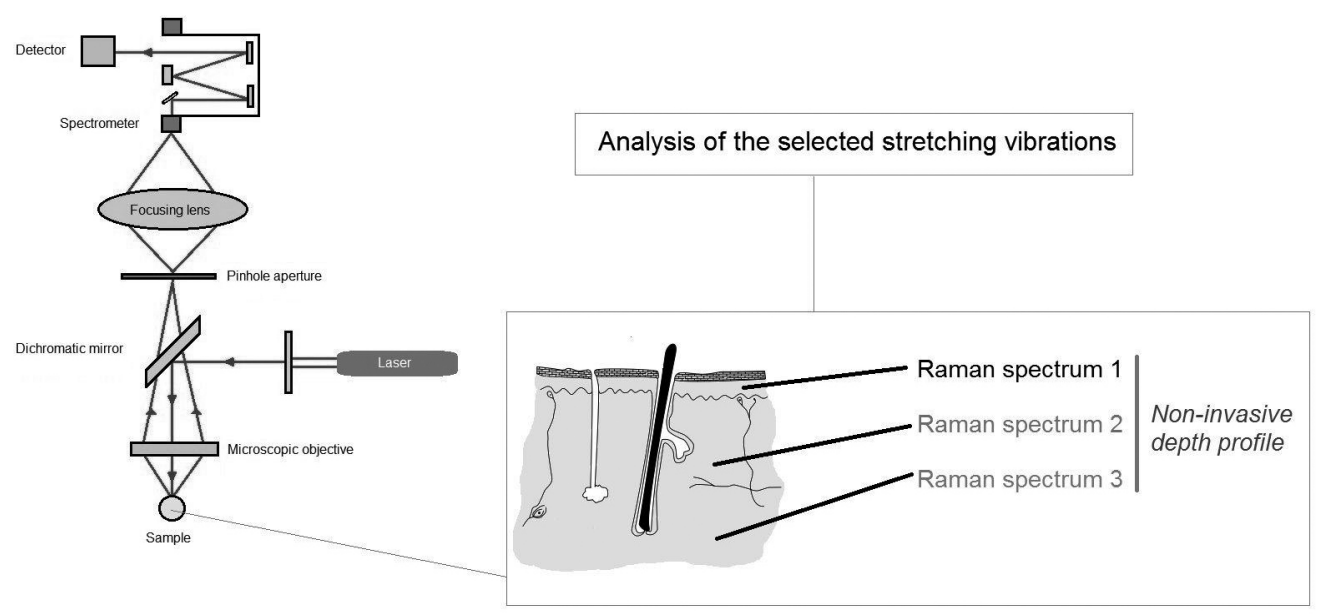

FIGURE 4 - Analysis using Raman confocal microscopy. 
by RCM for quantitative analysis of caffeine in skin was reported as an interesting non-invasive strategy for drug quantification directly in the skin by using a non-invasive technique (Franzen, Anderski, Windbergs, 2015).

\section{CONCLUSIONS}

Although there are different in vitro and in vivo methods for evaluation of the cutaneous absorption of drugs and bioactive molecules, pharmaceutical formulation scientists must select those best suited to their investigations. Thus, the success of topical and transdermal administration of drugs is directly related to the methods used for evaluation of the formulations, which enable optimization of the skin absorption of the drug so that it can reach effective drug concentrations at the therapeutic site.

\section{ACKNOWLEDGMENTS}

The authors are grateful for CAPES (Brasília, Brazil), CNPq (Brasília, Brazil), and Unifal-MG (Alfenas, Brazil) for research fellowships.

\section{REFERENCES}

ANDREWS, S.N.; JEONG, E.; PRAUSNITZ, M.R. Transdermal delivery of molecules is limited by full epidermis, not just stratum corneum. Pharm. Res., v.30, n.4, p.1099-109, 2013.

ALEXANDER, A.; DWIVEDI, S.; AJAZUDDIN; GIRI, T.K.; SARAF, S.; SARAF, S.; TRIPATHI, D.K. Approaches for breaking the barriers of drug permeation through transdermal drug delivery. J. Control. Rel., v.164, n.1, p.26-40, 2012.

ANISSIMOV, Y.G.; JEPPS, O.G.; DANCIK, Y.; ROBERTS, M.S. Mathematical and pharmacokinetic modelling of epidermal and dermal transport processes. Adv. Drug Deliv. Rev., v.65, n.2, p.169-190, 2013.

ASHTIKAR, M.; MATTHÄUS, C.; SCHMITT, M.; KRAFFT, C.; FAHR, A.; POPP, J. Non-invasive depth profile imaging of the stratum corneum using confocal Raman microscopy: First insights into the method. Eur. J. Pharm. Sci., v.50, n.5, p.601-608, 2013.

AZARMI, S.; ROA, W.; LÖBENBERG, R. Current perspectives in dissolution testing of conventional and novel dosage forms. Int. J. Pharm., v.328, n.1, p.12-21, 2007.
BAENA, J.R.; LENDL, B. Raman spectroscopy in chemical bioanalysis. Curr. Opin. Chem. Biol., v.8, n.5, p.534-539, 2004.

BALÁZS, B.; FARKAS, G.; BERKESI, O.; GYULAI, R.; BERKÓ, S.; BUDAI-SZÜCS, M.; SZABÓ-RÉVÉSZ, P.; KEMÉNY, L.; CSÁNYI, E. Protein structure is changed in psoriatic skin on the unaffected region - Imaging possibility with ATR-FTIR spectroscopy. Microchem. J., v.117, p.183186, 2014.

BARRY, B.W. Novel mechanisms and devices to enable successful transdermal drug delivery. Eur. J. Pharm. Sci., v.14, n.2, p.101-114, 2001

BERNARD, G.; AUGER, M.; SOUCY, J.; POULIOT, R. Physical characterization of the stratum corneum of an in vitro psoriatic skin model by ATR-FTIR and Raman spectroscopies. Biochim. Biophys. Acta, v.1770, n.9, p.1317-1323, 2007.

BOJAR, R.A. Studying the human skin microbiome using 3D in vitro skin models. Applied In Vitro Toxicol., v.1, n.2, p.165-71, 2015 .

BROWN, C.K.; CHOKSHI, H.P.; NICKERSON, B.; REED, R.A; ROHRS, B.R.; SHAH, P.A. Acceptable analytical practices for dissolution testing of poorly soluble compounds. Pharm. Technol., v.28, n.12, p.56, 2004.

BRUNNER, M.; DERENDORF, H. Clinical microdialysis: Current applications and potential use in drug development. TrAC Trends in Anal. Chem., v.25, n.7, p.674-680, 2006.

CARDOT, J.; BEYSSAC, E.; ALRIC, M. In vitro-in vivo correlation: Importance of dissolution in IVIVC. Dissol. Technol., p.15-19, 2007.

CASPERS, P.J.; LUCASSEN, G.W.; CARTER, E.A; BRUINING, H.A; PUPPELS, G.J. In vivo confocal Raman microspectroscopy of the skin: Noninvasive determination of molecular concentration profiles. J. Invest. Dermatol., v.116, n.3, p.434-442, 2001.

CASPERS, P.J.; LUCASSEN, G.W.; WOLTHUIS, R.; BRUINING, H. A.; PUPPELS, G.J. In vitro and in vivo Raman spectroscopy of human skin. Biospectroscopy, v.4, n.5 Suppl, p.S31-S39, 1998. 
CERBAI, F.; GIOVANNINI, M.G.; MELANI, C.; ENZ, A.; PEPEU, G. N1phenethyl-norcymserine, a selective butyrylcholinesterase inhibitor, increases acetylcholine Release in rat cerebral cortex: A comparison with donepezil and rivastigmine. Eur. J. Pharmacol., v.572, n.2-3, p.142$50,2007$.

CEVC, G.; VIERL, U. Nanotechnology and the transdermal route. A state of the art review and critical appraisal. $J$. Control. Release, v.141, n.3, p.277-299, 2010.

CHEN, J.; HU, W.; QU, Y.Q.; DONG, J.; GU, W.; GAO, Y.; FANG, Y.; FANG, F.; CHEN, Z.P.; CAI, B.C. Evaluation of the pharmacodynamics and pharmacokinetics of brucine following transdermal administration. Fitoterapia, v.86, n.1, p.193-201, 2013.

CHEN, L.; HAN, L.; LIAN, G. Recent advances in predicting skin permeability of hydrophilic solutes. Adv. Drug Deliv. Rev., v.65, n.2, p.295-305, 2013.

CHOI, J.; CHOI, M.-K.; CHONG, S.; CHUNG, S.-J.; SHIM, C.-K.; KIM, D.-D. Effect of fatty acids on the transdermal delivery of donepezil: In vitro and in vivo evaluation. Int. J. Pharm., v.422, n.1-2, p.83-90, 2012.

COSTA, P.; SOUSA LOBO, J.M. Modeling and comparison of dissolution profiles. Eur. J. Pharm. Sci., v.13, n.2, p.123$133,2001$.

DARLENSKI, R.; SASSNING, S.; TSANKOV, N.; FLUHR, J. W. Non-invasive in vivo methods for investigation of the skin barrier physical properties. Eur. J. Pharm. Biopharm., v.72, n.2, p.295-303, 2009.

DAS, R.S.; AGRAWAL, Y.K. Raman spectroscopy: Recent advancements, techniques and applications. Vib. Spectrosc., v.57, n.2, p.163-176, 2011.

DELGADO-CHARRO, M.B.; GUY, R.H. Effective use of transdermal drug delivery in children. Adv. Drug Deliv. Rev., v.73, p.63-82, 2014.

DESAI, P.R.; SHAH, P.P.; HAYDEN, P.; SINGH, M. Investigation of follicular and non-follicular pathways for polyarginine and oleic acid modified nanoparticles. Pharm. Res., v.30, n.4, p.1037-49, 2013.
DOS SANTOS, M.; METRAL, E.; BOHER, A.; ROUSSELLE, P.; THEPOT, A.; DAMOUR, O. In vitro 3-Dmodel based on extending time of culture for studying chronological epidermis aging. Matrix Biol., v.47, p.85-97, 2015.

EL MAGHRABY, G.M.; BARRY, B.W.; WILLIAMS, A.C. Liposomes and skin: From drug delivery to model membranes. Eur. J. Pharm. Sci., v.34, n.4-5, p.203-222, 2008.

FARAHMAND, S.; MAIBACH, H.I. Transdermal drug pharmacokinetics in man: Interindividual variability and partial prediction. Int. J. Pharm., v.367, n.1-2, p.1-15, 2009.

FOUAD, S.A.; BASALIOUS, E.B.; EL-NABARAWI, M.A.; TAYEL, S.A. Microemulsion and poloxamer microemulsion-based gel for sustained transdermal delivery of diclofenac epolamine using in-skin drug depot: In vitro/in vivo evaluation. Int. J. Pharm., v.453, n.2, p.569-578, 2013.

FRANZEN, L.; ANDERSKI, J.; WINDBERGS, M. Quantitative detection of caffeine in human skin by confocal Raman spectroscopy - A systematic in vitro validation study. Eur. J. Pharm. Biopharm., v.95, pt.A, p. 110-116, 2015.

FRANZEN, L.; SELZER, D.; FLUHR, J.W.; SCHAEFER, U.F.; WINDBERGS, M. Towards drug quantification in human skin with confocal Raman microscopy. Eur. J. Pharm. Biopharm., v.84, n.2, p.437-444, 2013.

FRASCH, H.F.; BARBERO, A.M. Application of numerical methods for diffusion-based modeling of skin permeation. Adv. Drug Deliv. Rev.,v.65, n.2, p.208-220, 2013.

FRUM, Y.; KHAN, G.M.; SEFCIK, J.; ROUSE, J.; ECCLESTON, G.M.; MEIDAN, V.M. Towards a correlation between drug properties and in vitro transdermal flux variability. Int. J. Pharm., v.336, n. 1, p.140-147, 2007.

GANNU, R.; VISHNU, Y.V.; KISHAN, V.; RAO, Y.M. Development of nitrendipine transdermal patches: In vitro and ex vivo characterization. Curr. Drug Deliv., v.4, n.1, p.69-76, 2007.

GODIN, B.; TOUITOU, E. Transdermal skin delivery: Predictions for humans from in vivo, ex vivo and animal models. Adv. Drug Deliv. Rev., v.59, n.11, p.1152-1161, 2007. 
GOTZ, C.; PFEIFFER, R.; TIGGES, J.; BLATZ, V.; JACKH, C.; FREYTAG, E.; FABIAN, E.; LANDSIEDEL, R.; MERK, H.F.; KRUTMANN, J.; EDWARDS, R.J.; PEASE, C.; GOEBEL, C.; HEWITT, N.; FRITSCHE, E. Xenobiotic metabolism capacities of human skin in comparison with a 3D epidermis model and keratinocytebased cell culture as in vitro alternatives for chemical testing: activating enzymes (Phase I). Exp. Dermatol., v.21, n.5, p.364-9, 2012.

GRATIERI, T.; KALIA, Y.N. Mathematical models to describe iontophoretic transport in vitro and in vivo and the effect of current application on the skin barrier. Adv. Drug Deliv. Rev., v.65, n.2, p.315-329, 2013.

GRATIERI, T.; GELFUSO, G.M.; LOPEZ., R.V. F. Basic principles and aplications of iontophoresis for cutaneous penetration of drugs. Quim. Nova, v.31, n.6, p.1490-1498, 2008.

GROEBER, F.; HOLEITER, M.; HAMPEL, M.; HINDERER, S.; SCHENKE-LAYLAND, K. Skin tissue engineering - In vivo and in vitro applications. Adv. Drug Deliv. Rev., v.63, n.4, p.352-366, 2011

GUPTA, R.R.; JAIN, S.K.; VARSHNEY, M. AOT Water-in-oil microemulsions as a penetration enhancer in transdermal drug delivery of 5-fluorouracil. Colloids Surf. B Biointerf., v.41, n.1, p.25-32, 2005.

GUPTA, S.K.; BENOWITZ, N.L.; JACOB, P.; ROLF, C.N.; GORSLINE, J. Bioavailability and absorption kinetics of nicotine following application of a transdermal system. $\mathrm{Br}$. J. Clin. Pharm., v.36, n.3, p.221-227, 1993.

GUTH, K.; SCHÄFER-KORTING, M.; FABIAN, E.; LANDSIEDEL, R.; VAN RAVENZWAAY, B. Suitability of skin integrity tests for dermal absorption studies in vitro. Toxicol. In Vitro, v.29, n.1, p.113-123, 2015.

HAAG, S.F.; FLEIGE, E.; CHEN, M.; FAHR, A.; TEUTLOFF, C.; BITTL, R.; LADEMANN, J.; SCHÄFER-KORTING, M.; HAAG, R.; MEINKE, M.C. Skin penetration enhancement of core-multishell nanotransporters and invasomes measured by electron paramagnetic resonance spectroscopy. Int. J. Pharm., v.416, n.1, p.223-228, 2011.

HANSON, R. A primer on release-rate testing of semisolids. Dissol. Technol., v.17, n.4, p.33-35, 2010.
HEARD, C.M.; JOHNSON, S.; MOSS, G.; THOMAS, C.P. In vitro transdermal delivery of caffeine, theobromine, theophylline and catechin from extract of guarana, Paullinia Cupana. Int. J. Pharm., v.317, n.1, p.26-31, 2006.

HÖCHT, C.; OPEZZO, J.A.W.; TAIRA, C.A. Applicability of reverse microdialysis in pharmacological and toxicological studies. J. Pharmacol. Toxicol. Meth., v.55, n.1, p.3-15, 2007.

JANU゚ŠOVÁ, B.; ŠKOLOVÁ, B.; TÜKÖROVÁ, K.; WOJNAROVÁ, L.; ŠIMU゚NEK, T.; MLADĚNKA, P.; FILIPSKÝ, T.; ŘÍHA, M.; ROH, J.; PALÁT, K.; HRABÁLEK, A.; VÁVROVÁ, K. Amino acid derivatives as transdermal permeation enhancers. J. Control. Release, v.165, n.2, p.91-100, 2013.

JEPPS, O.G.; DANCIK, Y.; ANISSIMOV, Y.G.; ROBERTS, M.S. Modeling the human skin barrier - Towards a better understanding of dermal absorption. Adv. Drug Deliv. Rev., v.65, n.2, p.152-158, 2013.

JUNG, E.; KANG, Y.P.; YOON, I.S.; KIM, J.S.; KWON, S.W.; CHUNG, S.J.; SHIM, C.K.; KIM, D.D. Effect of permeation enhancers on transdermal delivery of fluoxetine: In vitro and in vivo evaluation. Int. J. Pharm., v.456, n.2, p.362$369,2013$.

K. HURTADO, F.; LAUREANO, J.V.; DE A. LOCK, G.; DERENDORF, H.; DALLA COSTA, T. Enhanced penetration of moxifloxacin into rat prostate tissue evidenced by microdialysis. Int. J. Antimicrob. Agents, v.44, n.4, p.327-333, 2014.

KALIA, Y.N.; GUY, R.H. Modeling transdermal drug release. Adv. Drug Deliv. Rev., v.48, n.2-3, p.159-172, 2001.

KARADZOVSKA, D.; BROOKS, J.D.; MONTEIRORIVIERE, N.A.; RIVIERE, J.E. Predicting skin permeability from complex vehicles. Adv. Drug Deliv. Rev., v.65, n.2, p.265-277, 2013.

KIM, M.K.; ZHAO, H.; LEE, C.H.; KIM, D.D. Formulation of a reservoir-type testosterone transdermal delivery system. Int. J. Pharm., v.219, n.1-2, p.51-59, 2001.

KLANG, V.; SCHWARZ, J.C.; LENOBEL, B.; NADJ, M.; AUBÖCK, J.; WOLZT, M.; VALENTA, C. In vitro vs. in vivo tape stripping: Validation of the porcine ear model and penetration assessment of novel sucrose stearate emulsions. Eur. J. Pharm. Biopharm., v.80, n.3, p.604-614, 2012. 
KREILGAARD, M. Assessment of cutaneous drug delivery using microdialysis. Adv. Drug Deliv. Rev., v.54 Suppl 1, p.S99-121, 2002.

LEVEQUE, N.; MAKKI, S.; HADGRAFT, J.; HUMBERT, P. Comparison of Franz cells and microdialysis for assessing salicylic acid penetration through human skin. Int. J. Pharm., v.269, n.2, p.323-328, 2004.

LEWIS, D.; PAULO, M.; FAUSTINO, E. In vitro comparative studies of transdermal nicotine delivery systems. Int. J. Pharm., v.148, n.2, p.177-189, 1997.

LIN, S.; HO, H.; CHIEN, Y.W. Development of a new nicotine transdermal delivery system: In vitro kinetics studies and clinical pharmacokinetic evaluations in two ethnic groups. J. Control. Release, v.26, n.3, p.175-193, 1993.

LIU, N.; ZHANG, Y.; CUN, D.; QUAN, P.; FANG, L. Effect of Backing Films on the Transdermal Delivery of Conepezil from Patches. AAPS Pharm. Sci. Tech., v.15, p.1569-1573, 2014.

LOPES, L.B.; FERREIRA, D.A.; DE PAULA, D.; GARCIA, M.T.J.; THOMAZINI, J.A.; FANTINI, M.C.A; BENTLEY, M.V.L.B. Reverse hexagonal phase nanodispersion of monoolein and oleic acid for topical delivery of peptides: In vitro and in vivo skin penetration of cyclosporin A. Pharm. Res., v.23, n.6, p.1332-1342, 2006.

MADER, J.K.; FEICHTNER, F.; BOCK, G.; KÖHLER, G.; SCHALLER, R.; PLANK, J.; PIEBER, T.R.; ELLMERER, M. Microdialysis-A versatile technology to perform metabolic monitoring in diabetes and critically ill patients. Diabetes Res. Clin. Pract., v.97, n.1, p.112-118, 2012.

MANADAS, R.; PINA, M. E.; VEIGA, F. A dissolução in vitro na previsão da absorção oral de fármacos em formas farmacêuticas de liberação modificada. Rev. Bras. Ciênc. Farm., v.38, n.4, 2002.

MATEUS, R.; ABDALGHAFOR, H.; OLIVEIRA, G.; HADGRAFT, J.; LANE, M.E. A New Paradigm in dermatopharmacokinetics - Confocal Raman spectroscopy. Int. J. Pharm., v.444, n.1-2, p.106-8, 2013.

MATHES, S.H.; RUFFNER, H.; GRAF-HAUSNER, U. The use of skin models in drug development. Adv. Drug Deliv. Rev., v.69-70, p.81-102, 2014.
MATOS, B.N.; REIS, T.A.; GRATIERI, T.; GELFUSO, G.M. Chitosan nanoparticles for targeting and sustaining minoxidil sulphate delivery to hair follicles. Int. J. Biol. Macromol., v.75, p.225-9, 2015.

MCAULEY, W.J.; CHAVDA-SITARAM, S.; MADER, K.T.; TETTEH, J.; LANE, M.E.; HADGRAFT, J. The effects of esterified solvents on the diffusion of a model compound across human skin: An ATR-FTIR spectroscopic study. Int. J. Pharm., v.447, n.1-2, p.1-6, 2013.

MOSER, K.; KRIWET, K.; NAIK, A.; KALIA, Y.N.; GUY, R.H. Passive skin penetration enhancement and its quantification in vitro. Eur. J. Pharm. Biopharm., v.52, n.2, p.103-112, 2001.

NAEGEL, A.; HEISIG, M.; WITTUM, G. Detailed modeling of skin penetration- An overview. Adv. Drug Deliv. Rev., v.65, n.2, p.191-207, 2013.

NAIR, A.; JACOB, S.; AL-DHUBIAB, B.; ATTIMARAD, M.; HARSHA, S. Basic considerations in the dermatokinetics of topical formulations. Braz. J. Pharm. Sci., v.49, n.3, p.423-434, 2013.

NAIR, M.K.; CHETTY, D.J.; HO, H.; CHIEN, Y.W. Biomembrane permeation of nicotine: Mechanistic studies with porcine mucosae and skin. J. Pharm. Sci., v.86, n.2, p.257-262, 1997.

NAKASHIMA, K.; ITOH, K.; KONO, M.; NAKASHIMA, M.N.; WADA, M. Determination of donepezil hydrochloride in human and rat plasma, blood and brain microdialysates by HPLC with a short C30 column. J. Pharm. Biom. Anal., v.41, n.1, p.201-206, 2006.

NICOLI, S.; PENNA, E.; PADULA, C.; COLOMBO, P.; SANTI, P. New transdermal bioadhesive film containing oxybutynin: In vitro permeation across rabbit ear skin. Int. J. Pharm., v.325, n.1-2, p.2-7, 2006.

NISHIDA, N.; TANIYAMA, K.; SAWABE, T.; MANOME, Y. Development and evaluation of a monolithic drug-inadhesive patch for valsartan. Int. J. Pharm., v.402, n.1-2, p.103-109, 2010.

NOTMAN, R.; ANWAR, J. Breaching the skin barrier - Insights from molecular simulation of model membranes. Adv. Drug Deliv. Rev., v.65, n.2, p.237-250, 2013. 
NOVOTNÝ, M.; KLIMENTOVÁ, J.; JANƯŠOVÁ, B.; PALÁT, K.; HRABÁLEK, A.; VÁVROVÁ, K. Ammonium carbamates as highly active transdermal permeation enhancers with a dual mechanism of action. J. Control. Release, v.150, n.2, p.164-170, 2011.

OBATA, Y.; ASHITAKA, Y.; KIKUCHI, S.; ISOWA, K.; TAKAYAMA, K.A Statistical approach to the development of a transdermal delivery system for ondansetron. Int. $J$. Pharm., v.399, n.1-2, p.87-93, 2010.

OLIVEIRA, G.; LEVERETT, J.C.; EMAMZADEH, M.; LANE, M.E. The effects of heat on skin barrier function and in vivo dermal absorption. Int. J. Pharm., v.464, n.1-2, p.145-151, 2014.

PALECO, R.; VUČEN, S.R.; CREAN, A.M.; MOORE, A.; SCALIA, S. Enhancement of the in vitro penetration of quercetin through pig skin by combined microneedles and lipid microparticles. Int. J. Pharm., v.472, n.1-2, p.206213,2014

PATNI, M.; PURANIK, P.; SONAWANE, A.; PANZADE, P. Transdermal iontophoretic delivery of timolol maleate. Braz. J. Pharm. Sci., v.48, n.4, p.819-827, 2012.

PAŽOUREKOVÁ, S.; HOJEROVÁ, J.; KLIMOVÁ, Z.; LUCOVÁ, M. Dermal absorption and hydrolysis of methylparaben in different vehicles through intact and damaged skin: Using a pig-ear model in vitro. Food Chem. Toxicol., v.59, p.754-765, 2013.

PEREIRA, G.R.; COLLETT, J.H.; GARCIA, S.B.; THOMAZINI, J.A.; VITÓRIA, M.; BADRA, L. Glycerol monooleate/solvents systems for progesterone transdermal delivery: Invitro permeation and microscopic studies. Rev. Bras. Ciênc. Farm.., v.38, n.1, p.55-62, 2002.

PRAUSNITZ, M.R.; LANGER, R. Transdermal drug delivery. Nat. Biotechnol., v.26, n.11, p.1261-1268, 2009.

REID, M.L.; BENAOUDA, F.; KHENGAR, R.; JONES, S.A.; BROWN, M.B. Topical corticosteroid delivery into human skin using hydrofluoroalkane metered dose aerosol sprays. Int. J. Pharm., v.452, n.1-2, p.157-165, 2013.

REN, C.; FANG, L.; LING, L.; WANG, Q.; LIU, S.; ZHAO, L.; HE, Z. Design and in vivo evaluation of an indapamide transdermal patch. Int. J. Pharm., v.370, n.1-2, p.129-135, 2009.
ROBERTS, J.A.; ROBERTS, M.S.; ROBERTSON, T.A.; CROSS, S.E.; LIPMAN, J. A novel way to investigate the effects of plasma exchange on antibiotic levels: Use of microdialysis. Int. J. Antimicrob. Ag., v.31, n 3, p.240-244, 2008.

RUELA, A.L.M.; PEREIRA, G.R. Design and evaluation of molecularly imprinted polymers as drug delivery systems. In: TIWARI, A.; UZUN, L. (Eds.) Advanced molecularly imprinting materials. Beverly: Wiley-Scrivener, 2017. p.413-454.

RUELA, A.L.M.; FIGUEIREDO, E.C.; PEREIRA, G.R. Molecularly imprinted polymers as nicotine transdermal delivery systems. Chem. Eng. J., v.248, p.1-8, 2014.

RUELA, A.L.M.; FIGUEIREDO, E.C.; PERISSINATO, A.G.; LIMA, A.C.Z.; PEREIRA, G.R. In vitro evaluation of transdermal nicotine delivery systems commercially available in Brazil. Braz. J. Pharm. Sci., v.49, n.3, p.579$588,2013$.

SALUJA, S.; KASHA, P.C.; PATURI, J.; ANDERSON, C.; MORRIS, R.; BANGA, A.K. A novel electronic skin patch for delivery and pharmacokinetic evaluation of donepezil following transdermal iontophoresis. Int. J. Pharm., v.453, n.2, p.395-399, 2013.

SCHNETZ, E.; FARTASCH, M. Microdialysis for the evaluation of penetration through the human skin barrier - a promising tool for future research? Eur. J. Pharm. Sci., v.12, n.3, p.165-174, 2001.

SCHWARZ, J.C.; PAGITSCH, E.; VALENTA, C. Comparison of ATR-FTIR spectra of porcine vaginal and buccal mucosa with ear skin and penetration analysis of drug and vehicle components into pig ear. Eur. J. Pharm. Sci., v.50, n.5, p.595-600, 2013.

SEKI, T.; WANG, A.; YUAN, D.; SASO, Y.; HOSOYA, O.; CHONO, S.; MORIMOTO, K. Excised porcine skin experimental systems to validate quantitative microdialysis methods for determination of drugs in skin after topical application. J. Control. Release, v.100, n.2, p.181-189, 2004. 
SELZER, D.; ABDEL-MOTTALEB, M.M.A; HAHN, T.; SCHAEFER, U.F.; NEUMANN, D. Finite and infinite dosing: Difficulties in measurements, evaluations and predictions. Adv. Drug Deliv. Rev., v.65, n.2, p.278-294, 2013.

SHAH, S.M.; ASHTIKAR, M.; JAIN, A.S.; MAKHIJA, D.T.; NIKAM, Y.; GUDE, R.P.; STEINIGER, F.; JAGTAP, A.A.; NAGARSENKER, M.S.; FAHR, A. LeciPlex, invasomes, and liposomes: A skin penetration study. Int. J. Pharm., v.490, n.1-2, p.391-403, 2015.

SHANNON, R.J.; CARPENTER, K.L.H.; GUILFOYLE, M.R.; HELMY, A.; HUTCHINSON, P.J. Cerebral microdialysis in clinical studies of drugs: Pharmacokinetic applications. $J$. Pharmacokinet. Pharmacodyn., v.40, n.3, p.343-358, 2013.

SHEARMAN, E.; ROSSI, S.; SZASZ, B.; JURANYI, Z.; FALLON, S.; POMARA, N.; SERSHEN, H.; LAJTHA, A. Changes in cerebral neurotransmitters and metabolites induced by acute donepezil and memantine administrations: A microdialysis study. Brain Res. Bull., v.69, n.2, p.204$213,2006$.

SHINKAI, N.; KORENAGA, K.; OKUMURA, Y.; MIZU, H.; YAMAUCHI, H. Microdialysis assessment of percutaneous penetration of ketoprofen after transdermal administration to hairless rats and domestic pigs. Eur. J. Pharm. Biopharm., v.78, n.3, p.415-421, 2011.

SIEWERT, M.; DRESSMAN, J.; BROWN, C.K.; SHAH, V.P. FIP/AAPS Guidelines for dissolution/in vitro release testing of novel/special dosage forms. AAPS PharmSciTech, v.4, n.1, p.43-52, 2003.

S N ORR A D Ó T T IR, B.S.; GUDNA S ON, P. I . ; THORSTEINSSON, F.; MÁSSON, M. Experimental design for optimizing drug release from silicone elastomer matrix and investigation of transdermal drug delivery. Eur. J. Pharm. Sci., v.42, n.5, p.559-567, 2011.

SUBEDI, R.K.; RYOO, J.P.; MOON, C.; CHUN, M.K.; CHOI, H.K. Formulation and in vitro evaluation of transdermal drug delivery system for donepezil. J. Pharm. Investig., v.42, n.1, p.1-7, 2012.

TANG, Z.; WANG, Q.; XU, H.; ZHANG, W. Microdialysis sampling for investigations of tetramethylpyrazine following transdermal and intraperitoneal administration. Eur. J. Pharm. Sci., v.50, n.3-4, p.454-458, 2013.
TETTEY-AMLALO, R.N.O.; KANFER, I.; SKINNER, M.F.; BENFELDT, E.; VERBEECK, R.K. Application of dermal microdialysis for the evaluation of bioequivalence of a ketoprofen topical gel. Eur. J. Pharm. Sci., v.36, n.2-3, p.219-225, 2009.

THAKKER, K.; CHERN, W. Development and validation of in vitro release tests for semisolid dosage forms - Case study. Dissol. Technol., p.10-15, May, 2003.

TOJO, K.; KESHARY, P.R.; CHIEN, Y.W. Drug permeation trhough skin from matrix-type drug delivery systems. Chem. Eng. J., v.32, n.3, p.B57-B64, 1986.

VALENTA, C.; AUNER, B.G. The use of polymers for dermal and transdermal delivery. Eur. J. Pharm. Biopharm., v.58, n.2, p.279-289, 2004.

VICENTINI, F.T.M.C.; SIMI, T.R.M.; DEL CIAMPO, J.O.; WOLGA, N.O.; PITOL, D.L.; IYOMASA, M.M.; BENTLEY, M.V.L.B.; FONSECA, M.J.V. Quercetin in w/o microemulsion: In vitro and in vivo skin penetration and efficacy against UVB-induced skin damages evaluated in vivo. Eur. J. Pharm. Biopharm., v.69, n.3, p.948-957, 2008.

WANG, K.; YAN, Y.; ZHAO, G.; XU, W.; DONG, K.; YOU, C.; ZHANG, L.; XING, J. In vitro and in vivo application of hydroxypropyl- $\beta$-cyclodextrin-grafted polyethyleneimine used as a transdermal penetration enhancer. Polym. Chem., v.5, n.16, p.4658-4669, 2014.

WANG, Q.; MA, D.; HIGGINS, J.P. Drug product dissolution testing. Dissol. Technol., v.13, n.3, p.6-13, 2006.

WILDING, I.R.; DAVIS, S.S.; RIMOY, G.H.; RUBIN, P.; KURIHARA-BERGSTROM, T.; TIPNIS, V.; BERNER, B.; NIGHTINGALE, J. Pharmacokinetic evaluation of transdermal buprenorphine in man. Int. J. Pharm., v.132, n.1-2, p.81-87, 1996.

WILLIAMS, A.C.; BARRY, B.W. Penetration enhancers. $A d v$. Drug Deliv. Rev., v.64, p.128-137, 2012.

WOKOVICH, A.M.; PRODDUTURI, S.; DOUB, W.H.; HUSSAIN, A.S.; BUHSE, L.F. Transdermal drug delivery system (TDDS) adhesion as a critical safety, efficacy and quality attribute. Eur. J. Pharm. Biopharm., v.64, n.1, p.18,2006 . 
WU, J.; PAUDEL, K.S.; STRASINGER, C.; HAMMELL, D.; STINCHCOMB, A.L.; HINDS, B.J. Programmable transdermal drug delivery of nicotine using carbon nanotube membranes. Proc. Natl. Acad. Sci. U. S. A., v.107, n.26, p.11698-11702, 2010.

YAMASHITA, F.; HASHIDA, M. Mechanistic and empirical modeling of skin permeation of drugs. Adv. Drug Deliv. Rev., v.55, n.9, p.1185-1199, 2003.

YANG, J.-A.; KIM, E.-S.; KWON, J.H.; KIM, H.; SHIN, J.H.; YUN, S.H.; CHOI, K.Y.; HAHN, S.K. Transdermal delivery of hyaluronic acid - Human growth hormone conjugate. Biomaterials, v.33, n.25, p.5947-5954, 2012.

YANG, Y.; MANDA, P.; PAVURALA, N.; KHAN, M.A.; KRISHNAIAH, Y.S.R. Development and validation of in vitro-in vivo correlation (IVIVC) for estradiol transdermal drug delivery systems. J. Control. Rel., v.210, p.58-66, 2015 .

YE, J.C.; ZENG, S.; ZHENG, G.L.; CHEN, G.S. Pharmacokinetics of huperzine A after transdermal and oral administration in beagle dogs. Int. J. Pharm., v.356, n.1-2, p.187-192, 2008.
ZHAN, X.; MAO, Z.; CHEN, S.; CHEN, S.; WANG, L. Formulation and evaluation of transdermal drug-delivery system of isosorbide dinitrate. Braz. J. Pharm. Sci., v.51, n.2, p.373-382, 2015.

ZHANG, M.-Y.; HUGHES, Z.A.; KERNS, E.H.; LIN, Q.; BEYER, C.E. Development of a liquid chromatography/ tandem mass spectrometry method for the quantitation of acetylcholine and related neurotransmitters in brain microdialysis samples. J. Pharm. Biom. Anal., v.44, n.2, p.586-93, 2007.

ZHANG, Y.; CHAN, H.F.; LEONG, K.W. Advanced materials and processing for drug delivery: The past and the future. Adv. Drug Deliv. Rev., v.65, n.1, p.104-120, 2013.

ZHAO, X.; LIU, J.P.; ZHANG, X.; LI, Y. Enhancement of transdermal delivery of theophylline using microemulsion vehicle. Int. J. Pharm., v.327, n.1-2, p.58-64, 2006.

ZORIN, S.; KUYLENSTIERNA, F.; THULIN, H. In vitro test of nicotine's permeability through human skin. Risk evaluation and safety aspects. Ann. Occup. Hyg., v.43, n.6, p.405-413, 1999.

Received for publication on $14^{\text {th }}$ October 2015 Accepted for publication on $15^{\text {th }}$ August 2016 